\title{
Beneficial effects of Neotyphodium lolii on the growth and the water status in perennial ryegrass cultivated under nitrogen deficiency or drought stress
}

\author{
C Ravel ${ }^{1 *}, \mathrm{C}_{\text {Courty }}{ }^{2}$, A Coudret ${ }^{2}$, G Charmet $^{1}$ \\ 'Station d'amélioration des plantes, Inra, F-63039 Clermont-Ferrand cedex 02; \\ ${ }^{2}$ Laboratoire de physiologie et biotechnologies végétales, université Blaise-Pascal, \\ campus universitaire des Cézeaux, F-63I77 Aubière cedex, France
}

(Received 11 February 1997; accepted 1 April 1997)

\begin{abstract}
Summary - Three perennial ryegrass clones infected and uninfected with Neotyphodium lolii (formerly Acremonium lolii) were studied to determine the impact of this endophytic fungus on plant growth and physiology under stress conditions. Plants were grown under controlled environmental conditions for 10 weeks and were subjected to: i) no stress (12 mM of N; no limiting water supply); ii) $\mathrm{N}$ deficiency; or iii) drought stress. In the absence of stress, infected and non-infected plants of all clones showed similar growth rates. Under N deficiency (2.33 mM), infected plants had $27 \%$ more tillers and $15 \%$ less dead leaves than uninfected plants, and they maintained their photosynthetic level. During drought stress $(0.7 \mathrm{MPa})$, the osmotic potential of the infected plants was $13 \%$ lower than that of uninfected plants and their tiller number was $10 \%$ greater than that of non-infected plants at the end of the drought stress period. Thus, in the three clones studied, the infection results in increased tolerance of host plants to abiotic stress especially as a result of better tillering.
\end{abstract}

ryegrass $=$ Lolium perenne $/$ endophyte $/$ drought stress $/ \mathrm{N}$ deficiency $/$ Neotyphodium lolii

Résumé - Effets positifs de Neotyphodium lolii sur la croissance et l'état hydrique de plants de ray-grass anglais soumis à une carence en azote ou à un stress hydrique. Ce travail a été effectué sur trois clones de ray-grass anglais infectés ou non par Neotyphodium lolii (antérieurement Acremonium lolii), afin de déterminer l'impact de ce champignon endophyte sur la croissance et la physiologie des plantes soumises à des conditions stressantes. Les plantes sont cultivées pendant 10 semaines sous environnement controlé dans différentes conditions : i) aucun stress (12 mM de $\mathrm{N}$; apport en eau non limitant); ii) carence en azote ; ou iii) stress hydrique. En l'absence de stress, les plantes saines et endophytées, des trois génotypes étudiés, présentent une croissance et un développement identiques. En conditions de carence en azote $(2,33 \mathrm{mM})$, les plantes endophytées présentent un tallage plus important de $25 \%$ et un nombre de feuilles mortes plus faible de $15 \%$ par rapport aux plantes non endophytées. De plus, les plantes infectées maintiennent leur activité photosynthétique. Pendant le stress hydrique $(0,7 \mathrm{MPa})$, le potentiel osmotique des plantes endophytées est inférieur de $13 \%$ par rapport à celui mesuré chez les plantes non endophytées et elles présentent également un tallage supérieur de $10 \%$ en fin de stress. Dans le matériel étudié, l'infection permet une meilleure croissance des plantes cultivées en conditions de carence en azote ou de stress hydrique en particulier grâce à un meilleur tallage.

ray-grass anglais = Lolium perenne /endophyte / stress hydrique / déficience en $\mathrm{N} /$ Neotyphodium lolii

Article communicated by Hervé Thiellement (Versailles)

* Correspondence and reprints.

Tel: (33) 04736243 10; fax: (33) 04736244 53; e-mail: ravel@clermont.inra.fr 


\section{INTRODUCTION}

Many grasses belonging to Poaceae harbour endophytic fungi (White, 1987). This family contains the genera Festuca and Lolium, which include economically important species used as forage or turf (eg, Lolium perenne, Festuca arundinacea, $F$ pratensis, $F$ rubra). Most species of these two genera contain seed-borne asymtomatic endophytic fungi. Christensen et al (1993) reported that perennial ryegrass ( $L$ perenne) can be infected by two taxonomic groups of endophytes, the most widespread being Neotyphodium lolii (Glenn et al, 1996) (formerly Acremonium lolii) whereas tall fescue ( $F$ arundinacea) can harbour three taxomonic groups of such fungi, the most frequent being $N$ coenophialum (formerly $A$ coenophialum).

Endophyte/grass associations are symbiotic, some of them (for instance with perennial ryegrass, tall fescue, meadow fescue) being mutualistic (Clay, 1988). They lead to improved grass resistance to biotic (cattle and insect herbivory, nematodes, etc) and abiotic (drought, flood, nutrient, etc) stresses (see reviews by Siegel et al, 1987 and Van Heeswijck and Mc Donald, 1992), while the fungi benefit from the association receiving nutrients, protection and improved dissemination. According to West (1994), these complex associations involve integrated physiological responses on the part of each organism in term of growth, water relations, nutrient acquisition and use, and secondary metabolite synthesis.

In the eastern USA, tall fescue is one of the most important pasture grasses and is generally endophyte infected. Infection could explain its wide adaptation and many studies have been developed in the USA to determine the influence of endophytes on tall fescue physiology in stressful conditions at the population or genetically identical material (clone) level (see reviews by Bacon, 1993 and West, 1994). Stresses most frequently studied are drought or nitrogen level. There are some reports using other stresses such as flooding (Arachevaleta et al, 1989), acid rain (Cheplick, 1993) or soil acidity (Belesky and Fedders, 1995).

As far as drought stress is concerned, it has been suggested that symbiotic tall fescue may i) conserve water more efficiently through leaf rolling (Arachevaleta et al, 1989) and stomatal closure, which reduces photosynthesis (Richardson et al, 1993), ii) extract water better than non-symbiotic plants through a better root growth (Belesky et al, 1989) and iii) have a better osmotic adjustment (Elmi et al, 1989) through a higher carbohydrate concentration, especially in the meristematic and growing zones, that could improve tiller survival and regrowth (Elmi and West, 1995).

The impact of endophytes on nitrogen metabolism of tall fescue has also been explored (Arechavelata et al, 1989; Lyons et al, 1990). According to these authors, symbiotic tall fescue utilizes nitrogen more efficiently than plants without endophytes owing to an increased activity of glutamate synthetase regardless of nitrogen level or form. This allows symbiotic tall fescue to be as productive as non-symbiotic tall fescue at low nitrogen level and to be more productive at high nitrogen level. However, efficient utilization of nitrogen seems to occur in mature plants only. This may explain the opposite results of Cheplick et al (1989) in seedlings.

However, recent studies (Richardson et al, 1993; Belesky et al, 1995 and Hill et al, 1996) have shown that interactions between plant and endophyte genotypes are prevalent. Therefore, it seems that endophyte mediated drought tolerance occurs only in specific combinations. Likewise, the different mechanisms observed in endophyte infected plants explaining their improved drought tolerance or avoidance depend on the specific associations.

As far as perennial ryegrass/endophyte associations are concerned, most studies have reported that endophyte infected perennial ryegrass outperformed endophyte-free ryegrass. For instance, Latch et al (1985) showed that Neotyphodium endophytes enhanced ryegrass growth under controlled conditions. Some results obtained from a field study showed that symbiotic perennial ryegrass showed better agronomic performances than non-symbiotic types in dry environments (Ravel et al, 1995). Such results also suggested an endophyte mediated drought acclimatation in perennial ryegrass. However, Lewis et al (1997) reported that endophyte infection did not influence growth and nitrogen economy of symbiotic perennial ryegrass growing in flowing solutions whatever the level and form of supplied nitrogen.

Up to now, there has been no report on the influence of perennial ryegrass endophytes upon host plant physiology under stressful conditions. Thus, the objectives of this study were to evaluate three cloned endophyte infected (EI) or uninfected (NI) perennial ryegrasses for differences in morphological and physiological responses to nitrogen rates and drought stress under controlled conditions. Such a study based 
on genetically similar material freed of endophyte avoids confounding endophyte and plant genotype effects.

\section{MATERIAL AND METHODS}

\section{Plant material}

Two EI plants came from a nursery used in a breeding programme of French wild populations of perennial ryegrass. These genotypes were called 1 and 2 . The third infected plant (genotype 3 ) belongs to Nui, a cultivar from New-Zealand. The endophyte was isolated from each plant and it was established that all of them harboured Neotyphodium lolii.

The three genotypes were vegetatively propagated by separating tillers. NI plants were produced by growing some tillers from each EI plant on sand containing 0.25 g.L $\mathrm{L}^{-1}$ benomyl for 6 weeks, as described by Latch and Christensen (1982). EI and NI plants were split regularly over a period of 6 months before the start of the experiment. This period allowed the elimination of any possible effect of the fungicide on NI clone physiology. The plants were checked periodically to confirm the presence or absence of $N$ lolii by microscopic examination of the internal epidermis of the leaf sheath stained with aniline blue (Latch and Christensen, 1982). When sufficient tillers with three leaves were available, ten tillers for each combination were placed into pots $(25$ by $15 \mathrm{~cm}$ ) filled with vermiculite and irrigated by Coïc and Lesaint (1973) nutrient solution.

\section{Growing conditions}

Plants were placed in a controlled environment with 16 $\mathrm{h}$ photoperiod under $115 \mu \mathrm{mol} . \mathrm{m}^{-2} . \mathrm{s}^{-1}$ PFD (fluorescent + incandescent 400-700 $\mathrm{nm}$ ) maintained at $23 \pm 1{ }^{\circ} \mathrm{C}, 40 \pm 10 \%$ relative humidity by day, and $18 \pm 1^{\circ} \mathrm{C}, 70 \pm 10 \%$ relative humidity by night. Tillers were irrigated by Coïc and Lesaint (1973) nutrient solution $\left(\mathrm{K}^{+}, 3.80 \mathrm{mM} ; \mathrm{Ca}^{2+}, 2.50 \mathrm{mM} ; \mathrm{SO}_{4}^{-2-}, 0.75 \mathrm{mM}\right.$; $\mathrm{Mg}^{2+}, 75 \mathrm{mM} ; \mathrm{H}_{2} \mathrm{PO}_{4}^{-}, 0.80 \mathrm{mM}$ and $\mathrm{N}^{+}$, its level depending on the conditions; with micronutrients as in Coïc and Lesaint, 1973).

In the first study, two levels of nitrogen were used. Tillers of each combination received nutrient solution containing either $12 \mathrm{mM}$ of nitrogen ('standard' $\mathrm{N}$ level) or $2.33 \mathrm{mM}$ of nitrogen (low $\mathrm{N}$ level) for 10 weeks. As irrigation was applied weekly with $1 \mathrm{~L}$ of this nutrient solution, each pot received either $12 \mathrm{mM}$ or $2.33 \mathrm{mM}$ of $\mathrm{N}$; the level of irrigation solution was adjusted to $1 \mathrm{~L}$ by manual addition of water every day.

In the second experiment, 60 tillers per combination were subjected to a 6-day drought stress, while the level of nitrogen was 'standard'. This drought stress was imposed by the addition of mannitol to the nutrient solution so as to decrease the osmotic potential from
-0.1 to $-0.7 \mathrm{MPa}$. Such a weak water stress was applied because perennial ryegrass is very sensitive to drought.

\section{Parameters measured}

\section{Growth parameters}

The number of tillers and leaves, the dry weight, and the percentage of green leaves were recorded. The leaf area of the plants was measured with a planimetre (Canon, France) and a data-processing software giving leaf area in square centimetres.

\section{Physiological parameters}

Water $\left(\psi_{\mathrm{w}}\right)$, osmotic $\left(\psi_{\mathrm{s}}\right)$ and pressure $\left(\psi_{\mathrm{p}}\right)$ potentials were also evaluated. Water potential was measured with a pressure chamber as described by Scholander et al (1964), osmotic potential was measured with an osmometer (Roebling, type 12/12 DR, Bioblock, France) and pressure potential was determined using the relation:

$$
\begin{gathered}
\psi_{\mathrm{w}}=\psi_{\mathrm{s}}+\psi_{\mathrm{p}} \\
\left(\psi_{\mathrm{w}} \text { and } \psi_{\mathrm{s}} \text { were negative and } \psi_{\mathrm{p}} \text { positive }\right) .
\end{gathered}
$$

Water and osmotic potentials were measured on all mature leaves of the oldest tiller of the plants.

Net photosynthesis was measured using an ADC Parkinson leaf chamber infrared analyser (ADC, France), $4 \mathrm{~h}$ after the beginning of the light period. At this time, gas exchanges were stable. All mature leaves of the oldest tiller were placed in the chamber of the analyser and they were collected thereafter for leaf area measurement.

For each group of parameters, some clones from each combination (three genotypes (two endophyte statuses) of the three culture conditions ('standard' conditions, $\mathrm{N}$ deficiency and drought stress)) were randomly harvested at each measurement date. Maintaining the same situation of soil competition in each pot implied collection of the same number of clonal plants. For genotype No 1, a kinetic study was carried out during the 70 days of culture with measurements made: i) each week for the plants grown under both $\mathrm{N}$ conditions and ii) one and six days after the beginning of the drought stress period and, one and eight days after the end of the drought stress period. For the other genotypes, data were collected at the end of the 70 days of culture for both $\mathrm{N}$ levels and at the end of the drought stress period (the 6th day).

\section{Statistical analysis}

All values used in the figures are the means of six measurements. The percentage of green leaves was transformed by arcsinus square root before an analysis of variance. 
As far as the nitrogen level is concerned, two analyses were performed. First, for genotype No 1 and for each nitogen level, a distribution-free method, Mann and Withney $U$ test, was used to compare the means of six measurements of the different parameters during the 10 weeks of culture between the endophyte statuses. Second, all the data were subjected to an analysis of variance with three main effects (plant genotype, endophyte status and nitrogen level) and all the interactions using proc ANOVA of SAS (1989). The least significant difference was computed to allow pairwise comparison of treatment means (Dagnélie, 1975).

Data collected from the second experiment (drought stress) were analysed using the same procedures with a model of analysis of variance having two main effects (plants genotype and endophyte status) and their interaction.

\section{RESULTS}

\section{Nitrogen treatment}

\section{Study of genotype No I during 70 d of culture}

Under 'standard' conditions, during $70 \mathrm{~d}$ of culture, no significant difference was seen between EI and NI plants regardless of the physiological parameters measured. Thus, for the sake of simplicity, the values obtained in these conditions are not presented in the figures.

Under $\mathrm{N}$ deficiency, up to the 42nd day of culture, pairwise tests detected no difference between EI and NI plants except for net photosynthesis (figs 1 and 2). However, after $42 \mathrm{~d}$ of culture, EI clones had significantly more tillers and leaves than NI. Moreover, EI clones yielded more than NI plants and had a greater percentage of green leaves and total leaf area. Generally, the net photosynthetic rate of NI plants was greater than that of the EI plants during the $70 \mathrm{~d}$ of culture (fig 2). The net photosynthetic rate of El plants was the same as that of the plants grown under 'standard' conditions (data not shown). So the nitrogen stress increased only the net photosynthesis of NI plants but did not change that of EI plants.

\section{Study of the three genotypes after $70 \mathrm{~d}$ of culture}

The analysis of variance showed that there is no significant interaction for tiller number, dry weight and total leaf area (table I). For these variables, the effect of nitrogen is always highly significant whereas the factor endophyte is only sig-

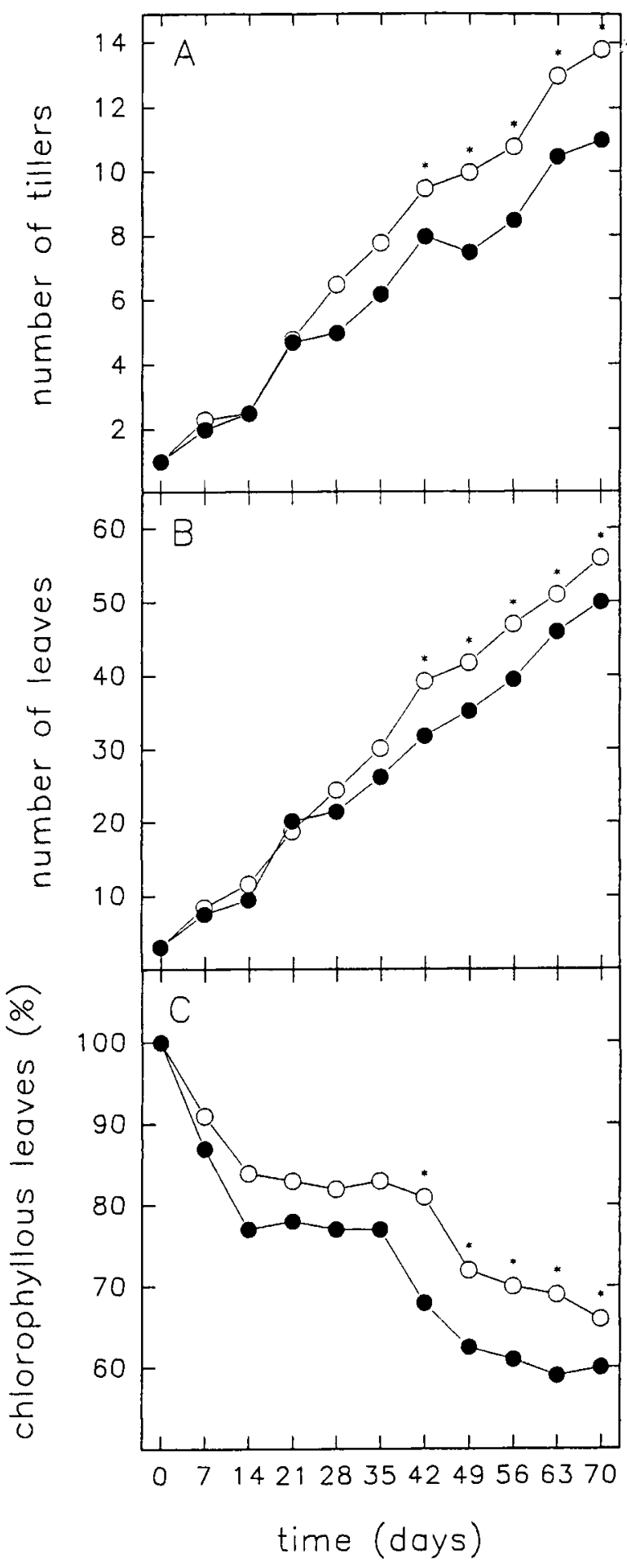

Fig 1. Evolution of number of tillers (A), number of leaves (B) and green leaf percentage (C) in ryegrass clone No 1 during 10 weeks of culture under nitrogen deficiency. Data were analysed with the Mann and Withney U test; * indicates significant difference between endophyte treatments for the low nitrogen level at $P=0.05$. $\bigcirc$ infected plants $(E I)$; uninfected plants (NI)

nificant for the number of tillers. EI plants had significantly more tillers than NI plants.

The other variables showed significant interactions mostly between endophyte status and nitro- 


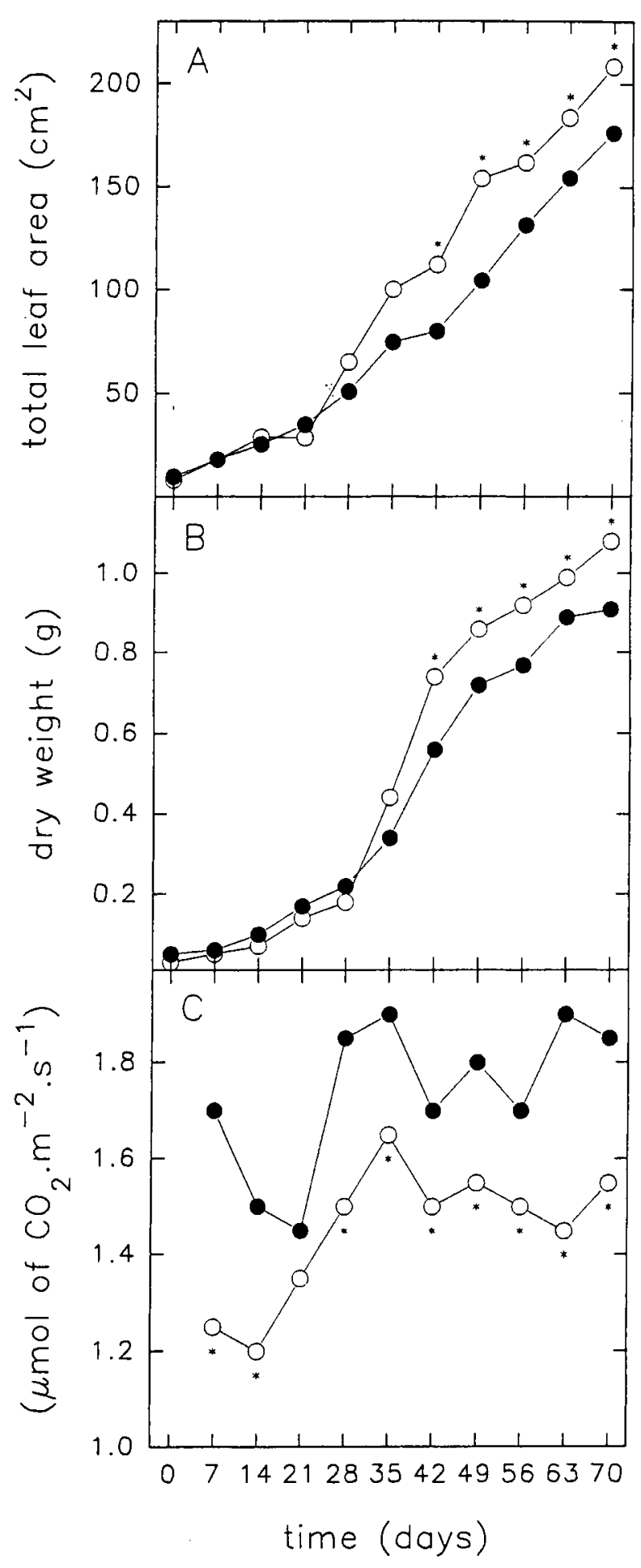

Fig 2. Evolution of total leaf area (A), dry weight (B) and net photosynthesis $(\mathrm{C})$ in ryegrass clone No 1 during 10 weeks of culture under nitrogen deficiency. Data were analysed with the Mann and Withney $\mathrm{U}$ test; * indicates significant difference between endophyte treatments for the low nitrogen level at $P=0.05$. $\bigcirc$ infected plants (NI); uninfected plants (NI).

gen level and once between host plant genotype and nitrogen. Thus, it is not possible to draw clear conclusions concerning each main effect. For these variables, means were separated by means of the least significant difference for each level of nitrogen (table II).

It can be seen (table II) that under 'standard' $\mathrm{N}$ conditions, there was no difference between NI clones and EI clones, while at low $\mathrm{N}$ level, EI clones significantly outperformed NI clones for the number of tillers and leaves, and the percentage of green leaves whereas their net photosynthesis was significantly lower than that of the NI clones. These results led to the same level of photosynthesis for both infection statuses: NI clones had less tillers and green leaves than EI plants but seemed able to maintain their photosynthesic activity through an increase in their net photosynthesis.

Values for water, osmotic and pressure potentials were not influenced by the $\mathrm{N}$ level.

\section{Drought stress}

\section{Study of the genotype No I during a 6-day drought stress}

When plants were not submitted to any drought stress, no significant difference was seen between EI and NI clones regardless of the physiological parameters measured. Consequently, to simplify, the values obtained under these conditions were not presented in the figures.

Concerning drought stress, the osmotic potential of EI plants decreased more during the stress and increased more rapidly after rewatering than that of NI clones (fig 3). Water potential being the same in both EI and NI clones, EI clones showed a significantly greater pressure potential (fig 3).

\section{Study of the three genotypes at the end of drought stress}

Generally, the analysis of variance showed no significant interaction between plant host genotype and endophyte status (table III). Therefore, it is possible to study the main effects and to compare the means by the Fisher's least significant difference. Significant differences exist for the factor endophyte for three variables (the number of tillers, osmotic and pressure potentials). EI clones had more tillers than NI clones after such a stress, whereas they had a lower osmotic potential. Consequently, EI plants had a significantly higher pressure potential than NI. Thus, EI clones showed more favourable osmotic (greater decrease) and pressure (greater increase) poten- 
Table I. ANOVA of yield components measured after $70 \mathrm{~d}$ of culture as influenced by host plant genotype, endophyte infection, nitrogen level and each interaction.

\begin{tabular}{|c|c|c|c|c|c|c|c|}
\hline \multirow[b]{2}{*}{ Variable } & \multicolumn{7}{|c|}{ Significance test } \\
\hline & geno & endo & nitro & geno*endo & geno*nitro & endo*nitro & geno*endo*nitro \\
\hline No of tillers & ns & $* * *$ & $* * *$ & ns & ns & $\mathrm{ns}$ & ns \\
\hline No of leaves & $* *$ & $*$ & $* * *$ & ns & ns & $*$ & $\mathrm{~ns}$ \\
\hline Dry weight (g.plant ${ }^{-1}$ ) & ns & ns & $* * *$ & ns & ns & $\mathrm{ns}$ & ns \\
\hline Total leaves area $\left(\mathrm{cm}^{2}\right)$ & $* * *$ & ns & $* * *$ & ns & ns & ns & ns \\
\hline Green leaves a & $* * *$ & $*$ & $* * *$ & ns & ns & $* *$ & ns \\
\hline $\begin{array}{l}\text { Net photosynthesis } \\
\left(\mu \mathrm{Mol} \text { of } \mathrm{CO}_{2} \cdot \mathrm{m}^{-2} \cdot \mathrm{s}^{-1}\right)\end{array}$ & $\mathrm{ns}$ & $* * *$ & $* * *$ & $\mathrm{~ns}$ & $* *$ & $* * *$ & $\mathrm{~ns}$ \\
\hline
\end{tabular}

geno, endo, nitro correspond to the three main effects, respectively plant genotype, endophyte status and nitrogen level. ${ }^{a}$ This variable corresponds to the transformed arcsin square root of the percentage of green leaves. ns $=$ no significant at $P>0.05$. $*, * *, * * *=$ significant F-test at $P \leq 0.05,0.01$ and 0.001 , respectively.

Table II. Effects of fungal endophyte on yield components of three genotypes of perennial ryegrass receiving different levels of nitrogen.

\begin{tabular}{lccc}
\hline & Endophyte & & Nitrogen level \\
\cline { 2 - 3 } Variable & status & standard $^{l}$ & low $^{l}$ \\
\hline Number of & Infected & $18.88(2.46) \mathrm{a}$ & $14.11(1.91) \mathrm{a}$ \\
tillers & Non Infected & $17.67(3.18) \mathrm{a}$ & $10.89(1.88) \mathrm{a}$ \\
Number of & Infected & $64.83(11.82) \mathrm{a}$ & $55.39(4.06) \mathrm{a}$ \\
leaves & Non Infected & $65.28(15.32) \mathrm{a}$ & $45.17(5.11) \mathrm{b}$ \\
Dry weight & Infected & $1.31(0.25) \mathrm{a}$ & $1.10(0.16) \mathrm{a}$ \\
(g.plant & Non Infected & $1.30(0.29) \mathrm{a}$ & $0.90(0.16) \mathrm{a}$ \\
Total leaves & Infected & $239.44(44.17) \mathrm{a}$ & $185.17(21.32) \mathrm{a}$ \\
area $\left(\mathrm{cm}^{2}\right)$ & Non Infected & $232.61(45.83) \mathrm{a}$ & $164.72(15.16) \mathrm{a}$ \\
Green leaves & Infected & $1.13(0.06) \mathrm{a}$ & $0.98(0.06) \mathrm{a}$ \\
& Non infected & $1.14(0.06) \mathrm{a}$ & $0.91(0.06) \mathrm{b}$ \\
Net photosynthesis & Infected & $1.53(0.11) \mathrm{a}$ & $1.57(0.10) \mathrm{b}$ \\
mMol of CO $\left._{2} \cdot \mathrm{m}^{-2} \cdot \mathrm{s}^{-1}\right)$ & Non Infected & $1.54(0.14) \mathrm{a}$ & $1.92(0.21) \mathrm{a}$ \\
\hline
\end{tabular}

When there are significant interactions, means were compared using the Fisher's LSD at $5 \%$ for each nitrogen level in order to avoid interactions. So, means followed by different letter were significantly different at $5 \%$. ${ }^{1}$ Values are the means of six replications, following by the standard deviation; ${ }^{2}$ this variable corresponds to the transformed arcsin square root of the percentage of green leaves.

Table III. Effects of endophyte on yield components and hydric parameters at the 6th day of water stress.

\begin{tabular}{|c|c|c|c|c|c|}
\hline \multirow[b]{2}{*}{ Variable } & \multicolumn{3}{|c|}{ Significance test } & \multicolumn{2}{|c|}{ Mean } \\
\hline & geno & endo & geno*endo & Infected & Non Infected \\
\hline Number of tillers & $* * *$ & $* *$ & ns & $18.39 \mathrm{a}$ & $16.72 \mathrm{~b}$ \\
\hline Number of leaves & ns & $\mathrm{ns}$ & ns & $62.39 \mathrm{a}$ & $59.89 \mathrm{a}$ \\
\hline Dry weight (g.plant ${ }^{-1}$ ) & ns & $\mathrm{ns}$ & ns & $1.22 \mathrm{a}$ & $1.20 \mathrm{a}$ \\
\hline Total leaves area $\left(\mathrm{cm}^{2}\right)$ & $* *$ & ns & ns & $209.56 \mathrm{a}$ & $210.44 \mathrm{a}$ \\
\hline Green leaves 1 & $*$ & $\mathrm{~ns}$ & ns & $1.16 \mathrm{a}$ & $1.15 \mathrm{a}$ \\
\hline $\begin{array}{l}\text { Net photosynthesis } \\
\left(\left(\mathrm{Mol} \text { of } \mathrm{CO}_{2} \cdot \mathrm{m}^{-2} \cdot \mathrm{s}^{-1}\right)\right.\end{array}$ & ns & ns & $*$ & $1.42 \mathrm{a}$ & $1.56 \mathrm{a}$ \\
\hline Osmotic potential (MPa) & ns & $*$ & ns & $-1.34 \mathrm{a}$ & $-1.26 b$ \\
\hline Water potential (MPa) & ns & $\mathrm{ns}$ & ns & $-0.79 \mathrm{a}$ & $-0.80 \mathrm{a}$ \\
\hline Pressure potential (MPa) & ns & $*$ & ns & $0.55 \mathrm{a}$ & $0.46 \mathrm{~b}$ \\
\hline
\end{tabular}

Means were compared using the Fisher's LSD at 5\%. So, means followed by different letters were significantly different at $5 \%$. geno, endo correspond to the main effects, respectively plant genotype and endophyte status. ${ }^{1}$ This variable corresponds to the transformed arcsin square root of the percentage of green leaves. ns $=$ no significant at $P>0.05 . *, * * * * *=$ significant F-test at $P \leq 0.05$, 0.01 and 0.001 , respectively. 


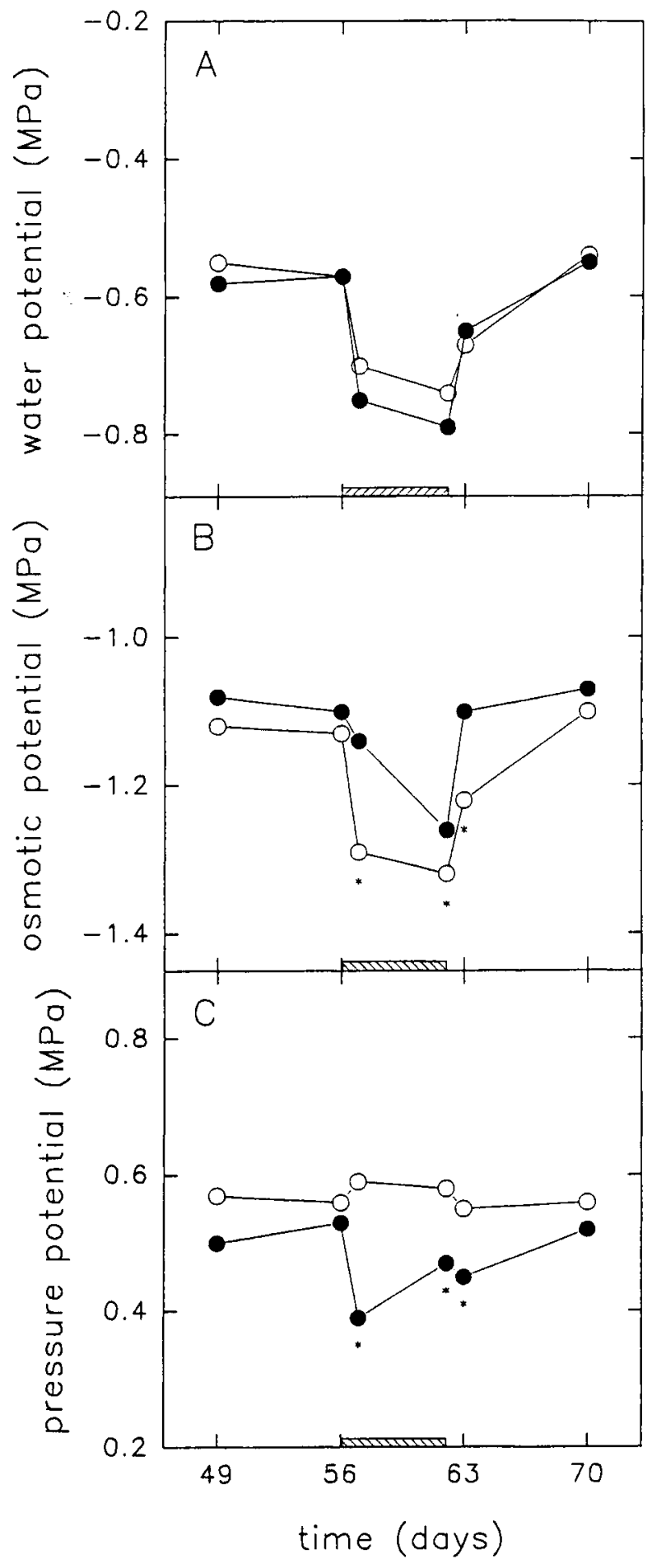

Fig 3. Evolution of water (A), osmotic (B) and pressure (C) potentials in ryegrass clone No 1 in response to a 6 daydrought stress. Data were analysed with the Mann and Withney $U$ test; * indicates significant difference between endophyte treatments for the low nitrogen level at $P=0.05$. $O$ infected plants (EI); uninfected plants (NI) $\ 1 \backslash \backslash$ water stress period. tials than NI clones in response to a drought stress, and a greater tiller number.

\section{DISCUSSION}

Significant differences between EI and NI plants are found only in the presence of environmental stress. Several authors (Latch et al, 1985; Cheplick et al, 1989) compared growth characteristics of EI and NI plants cultivated in optimum conditions and reported significant increases in growth parameters including tiller numbers, total leaf area, growth of leaves, dry matter yield owing to the presence of endophyte. Such differences were also reported by Belesky et al (1987) who studied the influence of endophyte on photosynthesis without stress. In contrast to these results, no differences were detected between EI and NI plants in the absence of stress. Thus, our results suggest that the endophyte can play an important role when plants are grown in the presence of an environmental stress such as $\mathrm{N}$ deficiency or drought.

Under $\mathrm{N}$ deficiency, EI plants had a greater number of tillers and leaves than NI plants although having the same dry weight. Such a result has already been reported by Lewis et al (1997) who found no significant difference for the dry weight of EI and NI clones of perennial ryegrass growing in flowing solutions with several levels and forms of nitrogen. In our experiment, EI plants also had a significantly higher percentage of green leaves than NI plants. Despite these results, EI plants maintained their photosynthetic activity at the same rate as the plants cultivated under 'standard' conditions whereas NI plants showed a significant increase in their net photosynthesis. All these results led to the conclusion that EI and NI plants had the same global photosynthesis under $\mathrm{N}$ deficiency, hence they had the same dry matter yield. Increases in net photosynthesis could also be seen as a response to stressful conditions. Thus, our results suggest that EI plants behaved as if they had undergone a less damaging nitrogen deficiency than NI plants. This could explain the reduced senescence phenomena (more green leaves) and the increased tillering of EI plants. EI plants seemed to be less stressed than NI ones under low levels of nitrogen. This indicates that the presence of the endophyte may affect either nitrogen nutrition or metabolism of the plant. According to Bacon et al. (1986) and Lyons et al. (1990), the second hypothesis seems more likely.

The differences observed between EI and NI plants for tillering and the number of leaves may 
have led to difference for the total leaf area and dry weight. This was not the case. So, it showed that leaf size as well as tiller weight appear to be affected by the endophyte, which seems therefore able to alter the morphology of its host. Such differences have already been reported in tall fescue by Arachevaleta et al (1989) who noticed that leaves of EI tall fescue are smaller than those of NI at low level of nitrogen, and by Hill et al. (1990) who showed that the presence of endophyte could increase the phenotypic variation of tall fescue. Thus, it seems that endophyte affects the phenotypic plasticity of growth traits of perennial ryegrass in response to different levels of nitrogen. This is in agreement with results obtained by Cheplick (1997) who reported that such plastic responses to nutrients exist in perennial ryegrass and can be affected by high levels of endophytic fungi.

In response to a drought stress, for the three ryegrass clones tested, EI plants showed a greater decrease in osmotic potential, which allowed a greater turgor maintenance and a better tillering. As far as osmotic potentials are concerned, such results were obtained by Elmi et al (1989) for symbiotic tall fescue. These authors suggested also that such an osmotic adjustment could be a mechanism by which endophyte imparted greater persistence in tall fescue plants during drought periods. Several authors, such as Arachevaleta et al (1989) and West et al (1990, 1993), showed that endophyte could also improve survival of symbiotic tall fescue during drought period by increasing tillering. So, our results are in agreement with results already published for tall fescue. Therefore, it seems that endophytes of tall fescue and perennial ryegrass are able to interact with their host in the same way. However, West et al (1988) reported that when water deficits occurred, herbage yield and leaf area were lower and percentage of dead tissue was greater in NI plants compared with the EI plants. The lack of significant differences for these parameters between EI and NI plants in our trial could be due either to an insufficient drought stress or to our specific plantendophyte combinations.

Our results therefore suggest that endophyte infection is of agronomic interest in abiotic stressful environmental conditions. However, several authors point out that beneficial effects of endophytes are the results of specific interactions between plant genotypes and endophyte isolates (Richardson et al, 1993; Belesky et al, 1995; Hill et al, 1996). Therefore, the extrapolation of results obtained under controlled conditions from clonal material to heterogeneous populations in the field is difficult and requires further studies. Despite these interactions, some field results confirm the agronomic benefit of endophytes in dry conditions (Ravel et al, 1995). The fact that endophytes could improve the nitrogen metabolism of its hosts has a huge agronomical interest as a way of decreasing nitrogen fertilisation and therefore the cost of input for farmers and also reducing the pollution of nitrate.

\section{ACKNOWLEDGEMENTS}

The authors are very grateful to $\mathrm{C}$ West for his critical reading and helpful comments on the manuscript. This work was supported by a grant from the Association des créateurs de variétés fourragères $(\mathrm{ACVF})$.

\section{REFERENCES}

Arachevaleta M, Bacon CW, Hoveland CS, Radcliffe DE (1989) Effect of the tall fescue endophyte on plant response to environmental stress. Agron $J 81$, 83-90

Bacon CW (1993) Abiotic stress tolerances (moisture, nutrients) and photosynthesis in endophyte-infected tall fescue. Agriculture, Ecosystems and Environment 44, 123-141

Bacon CW, Lyons PC, Porter JK, Robbins JD (1986) Ergot toxicity from endophyte-infected grasses: a review. Agron J 78, 106-116

Belesky DP, Fedders JM (1995) Tall fescue development in response to Acremonium coenophialum and soil acidity. Crop Sci 35, 529-533

Belesky DP, Devine OJ, Pallas JE Jr, Stringer WC (1987) Photosynthetic activity of tall fescue as influenced by a fungal endophyte. Photosynthetica 21 , 82-87

Belesky DP, Stringer WC, Hill NS (1989) Influence of endophyte and water regime upon tall fescue accessions. I. Growth characteristics. Ann Bot 63, 495503

Cheplick GC (1993) Effect of simulated acid rain on the mutualism between tall fescue (Festuca arundinacea) and an endophytic fungus (Acremonium coenophialum). Int J Plant Sci 154, 134-143

Cheplick GC (1997) Effect of endophytic fungi on the phenotypic plasticity of Lolium perenne (Poaceae). Am $J$ Bot (in press)

Cheplick GC, Clay K, Marks S (1989) Interaction between infection by endophytic fungi and nutrient limitation in the grasses Lolium perenne and Festuca arundinacea. New Phytol 111, 89-97

Christensen MJ, Leuchtmann A, Rowan DD, Tapper BA (1993) Taxonomy of Acremonium endophytes of tall fescue (Festuca arundinacea), meadow fes- 
cue ( $F$ pratensis) and perennial ryegrass (Lolium perenne). Mycol Res 97, 1083-1092

Clay K (1988) Fungal endophytes of grasses: a defensive mutualism between plants and fungi. Ecology $69,10-16$

Coïc Y, Lesaint C (1973) La nutrition minérale en horticulture avancée. Rev Hortic 2316, 29-34

Dagnélie P (1975) L'analyse de la variance à deux critères de classification. In: Théorie et méthodes statistiques. Applications agronomiques, Les presses agronomiques de Gembloux, Gembloux, 153-209

Elmi AA, West CP (1995) Endophyte infection effects on stomatal conductance, osmotic adjustment and drought recovery of tall fescue. New Phytol. 131, 6167

Elmi AA, West CP, Turner KE (1989) Acremonium endophyte enhances osmotic adjustement in tall fescue. Arkansas Farm Res 38, 4-17

Glenn AE, Bacon CW, Price R, Hanlin RT (1996) Molecular phylogeny of Acremonium and its taxonomic implications. Mycologia 88, 369-383

Hill NS, Stringer WC, Rottinghaus GE, Belesky DP, Parrott WA, Pope DD (1990) Growth, morphological and chemical component responses of tall fescue to Acremonium coenophialum. Crop Sci 30, 156-161

Hill NS, Pachon JG, Bacon CW (1996) Acremonium coenophialum-mediated short- and long-term drought acclimatation in tall fescue. Crop Sci 36, $665-672$

Latch GCM, Christensen MJ (1982) Ryegrass endophyte, incidence, and control. $N Z J$ Agric Res 25, 443-448

Latch GCM, Hunt WF, Musgrave DR (1985) Endophyte fungi affect growth of perennial ryegrass. N Z J Agric Res 28, 165-168

Lewis GC, Bakken AK, Macduff JH, Raistrick N (1997) Effect of infection by endophytic fungus Acremonium lolii on growth and nitrogen uptake by perennial ryegrass (Lolium perenne) in flowing solution culture. Ann Applied Biol (in press)

Lyons PC, Evans JE, Bacon CW (1990) Effects of the fungal endophyte Acremonium coenophialum on nitrogen accumulation and metabolism in tall fescue Plant Physiol 92, 726-732

Ravel C, Charmet G, Balfourier F (1995) Influence of the fungal endophyte Acremonium lolii on agronomic traits of perennial ryegrass in France. Grass and Forage Sci $50,75-80$

Richardson MD, Hoveland CS, Bacon CW (1993) Photosynthesis and stomatal conductance of symbiotic and non symbiotic tall fescue. Crop Sci 33, 145 149

SAS Institute Inc (1989) SAS/STAT User's guide, version 6, fourth Edition, volume 1. Cary, NC

Scholander PF, Hammel HT, Hemmingsen EA, Bradstreet ED (1964) Hydrostatic pressure and osmotic potential in leaves of mangroves and some other plants. Proc Natl Acad Sci USA 51, 119-125

Siegel MR, Latch CGM, Johnson MC (1987) Fungal endophytes of grasses. Ann Rev Phytopathol 25, 293-315

Van Heeswijck R., Mac Donald G (1992) Acremonium endophytes in perennial ryegrass and other pasture grasses in Australia and New-Zealand. Aust J Agric Res 43, 1683-1709

West CP (1994) Physiology and drought tolerance of Endophyte-infected grasses. In: Biotechnology of Endophytic Fungi of Grasses (CW Bacon, JF Jr White, eds), CRC Press, Boca Raton, FL, 87-98

West CP, Izekor E, Oosterhuis DM, Robbins RT (1988) The effect of Neotyphodium coenophialum on the growth and nematodes infestation of tall fescue. Plant Soil 112, 89-97

West CP, Oosterhuis DM, Wullschleger SD (1990) Osmotic adjustement in tissues of tall fescue in response to water deficit. Environ Exp Bot 30, 149. 156

West CP, Izecor E, Turner KE, Elmi AA (1993) Endophyte effects on growth and persistence of tall fescue along a water supply gradient. Agron $J 85$, 264-270

White JF Jr (1987) Widespread distribution of endophytes in the Poaceae. Plant Disease 71, 340-342 